IFN Working Paper No. 973, 2013

\title{
The Bracteate as Economic Idea and Monetary Instrument
}

\author{
Roger Svensson
}




\title{
The Bracteate as Economic Idea
}

\section{and Monetary Instrument}

\author{
Roger Svensson *
}

5 September 2013

\begin{abstract}
Key-words: Bracteates, medieval coins, re-coinage, short-lived coinage system, monetization, monetary taxation policy, small change

JEL: $\quad$ E31, E42, E52, N13
\end{abstract}

\begin{abstract}
Although the leaf-thin bracteates are the most fragile coins in monetary history, they were the main coin type for almost two centuries in large parts of medieval Europe. The usefulness of the bracteates can be linked to the contemporary monetary taxation policy. Medieval coins were frequently withdrawn by the coin issuer and re-minted, where people had to pay an exchange fee. Bracteates had several favourable characteristics for such a policy: 1) Low production costs; and 2) various pictures could be displayed given their relatively large diameter, making it easy to distinguish between valid and invalid types. The fragility was not a big problem, since the bracteates would not circulate for a long period. When monetization increased and it became more difficult to handle re-coinage (around 1300), the bracteates lost their function as the principal coin. However, for a further two centuries (1300-1500) they were used as small change to larger denominations.
\end{abstract}

* The Research Institute of Industrial Economics (IFN), P.O. Box 55665, SE-10215 Stockholm, Sweden. Correspondence: roger.svensson@ifn.se

I would like to thank Lars Jonung, Per Hortlund and Mikael Stenkula for insightful comments and Magnus Wijk, Uppsala, who has made available the photos. The author gratefully acknowledges financial support from the Torsten Söderberg Foundation. 


\section{Introduction}

Bracteates are thin uni-faced silver coins that were struck with only one die. A piece of soft material, such as leather or lead, was placed under the thin flan (Kühn 2000:1ff). Consequently, the design of the obverse can be seen as a mirror image on the reverse of the bracteates (see Picture 1). A common misunderstanding is that all uni-faced coins are bracteates. ${ }^{1}$ Uni-faced coins that have not been minted through the specific technology of using soft materials under the flan are not called bracteates. The diameter of the bracteates can vary from 10 to $50 \mathrm{~mm}$ and the weight is mostly between 0.05 and $1.00 \mathrm{~g}$. The bracteates are only $0.05-0.20 \mathrm{~mm}$ thin. They are the most fragile coins in monetary history, but a high relief often stabilizes the coins.
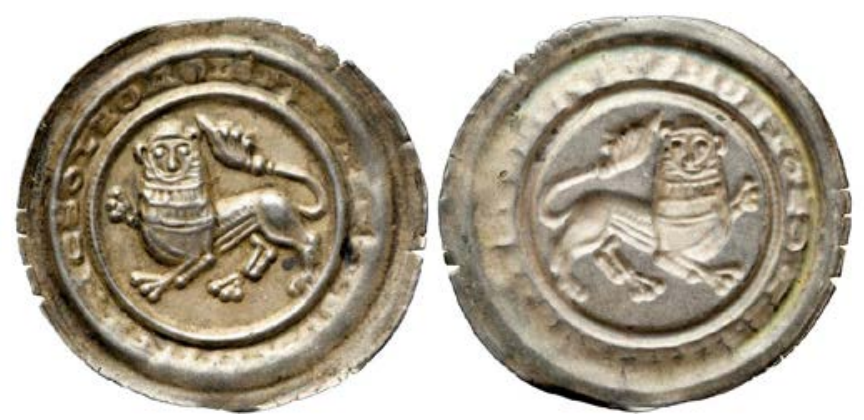

Picture 1. Obverse and reverse of a bracteate. Brunswick, Duke Henry the Lion (1142-92). Heraldic lion left, head facing, $0.71 \mathrm{~g}$, Ø $27 \mathrm{~mm}$. Legend: IEPNC.LEOELJVHHINRNCSOLEOA.

European bracteates were first struck in Germany in the 1120 s. $^{2}$ From the middle of the $12^{\text {th }}$ century to the beginning of the $13^{\text {th }}$ century the bracteate technology spread to neighbouring areas in central and eastern Europe as well as Scandinavia. ${ }^{3}$ The bracteate was the main coin type in these areas for 150-200 years (ca. 1140-1320). The coinage of bracteates only ceased completely in the late $16^{\text {th }}$ century.

\footnotetext{
${ }^{1}$ Mostly, a bracteate is defined as "a uni-faced thin coin". However, this definition is incomplete, since the term "thin" is subjective. The incomplete definition is likely the reason why any uni-faced coins are called bracteates in auction catalogues, in other literature and on the web. Using this definition, one has to precisely define how thin the uni-faced coin is.

${ }^{2}$ Here, Germany is defined as the northern parts of the medieval Holy-Roman Empire, which included the Germany of today as well as Upper Lusatia, Lower Lusatia, Silesia, Pomerania, eastern Prussia and parts of eastern France and northern Switzerland.

${ }^{3}$ Uni-faced bracteates had been minted in India in the $7^{\text {th }}$ and $8^{\text {th }}$ centuries, but they were struck from the reverse with a positively engraved die and had another design and higher weight (5.0-6.0 g) than the German bracteates. A link between Indian and German bracteates is doubtful. Jewellery bracteates have been found in hoards from the Migration period (ca. 300-800) in northern Europe, and were likely known to the medieval mint masters in northern and central Germany. But the jewellery bracteates were made of gold, and were neither produced with dies nor used as an everyday medium of exchange. However, there is a direct technological link between the minting of medieval bracteates and goldsmith's work. The common feature was that each technique involved working up thin flans of precious metal against a soft material.
} 
How could such fragile coins dominate the coinage in large parts of medieval Europe for more than 150 years? The bracteates have been carefully described in the archaeological and numismatic literature (see e.g. Kluge 2007), but the duration and scope of their use has not been connected to any economic theory. In this study, I link the bracteates to the monetary taxation policies that were at work in medieval Europe to explain this issue.

A goal of the minting authorities in medieval Europe was to create a preference for the issuer's coins compared to competing foreign coins, with sustained acceptance enhancing the coin issuer's profit. Therefore, legal tender laws typically stated that foreign coins were precluded from circulation. Foreign coins and bullion were to be exchanged for current coins at the mints. Here, the minting authority had an exchange monopoly and could thereby charge a gross seignorage (Kluge 2007:62-63).

A well-known monetary taxation method was to manipulate the weight and fineness of the coins. Such debasements are probably as old as coining itself and often occurred in times of war or epidemic when finances were volatile and in disarray (Edvinsson 2011:168). ${ }^{4}$ Profits from debasements were based on secrecy and asymmetric information about the fineness on the part of the coin issuer vis-à-vis the public. There were thus large transaction costs for people to detect debasements of fineness.

A less well-known way to profit from minting was re-coinage (also known as coin renewals or lat. renovatio monetae), i.e. old coins were declared invalid and exchanged for new ones at fixed exchange rates and dates. The monetary standard (denomination, weight, fineness, diameter, shape of the flan) remained the same at re-coinage, only the image of the coins was changed. An exchange fee was charged as a way to tax trade and inhabitants. The main purpose of this study is to theoretically and empirically analyze how monetary systems with re-coinage and the minting of bracteates coincided.

The study is organized as follows. In section 2, I describe the extension of short-lived and long-lived coinage systems through time and space in medieval Europe. Here, the theory and conditions of short-lived coinage system are also outlined. In section 3, I discuss and analyze why bracteates were so practical for frequent coin renewals. The difference between two-

\footnotetext{
${ }^{4}$ It is well-known that debasement are likely either the direct means of simply making higher profit from minting itself, or the indirect means to deflate accumulated debt.
} 
faced coins and uni-faced bracteates as short-lived coins is analyzed in section 4 . Section 5 discusses the end of the bracteates as the main coin type. The final section delineates several conclusions that can be drawn from this study of the life-cycle of a coinage system once taken for granted.

\section{Basics about medieval coins and coinage policies}

\subsection{Medieval coins}

A coin is a piece of hard material that is standardized in weight and fineness. An authority guarantees the weight and fineness with a hallmark. To work as general purpose money, coins must perform three basic functions: as a medium of exchange, a standard of value/unit of account and a store of value. Generally, coins in medieval Europe did all three jobs adequately, in the main as commodity money, i.e. the face value was very close to the intrinsic value. Fiat money where the value is not determined by the raw material value, but by the issuer's credibility, did not exist in pure form. ${ }^{5}$ If the weight or the fineness of commodity money declines, then the purchasing power of the coins also decreases. Precious metals (gold and silver) best fulfilled the requirements of commodity money and were used as raw materials in medieval coins. ${ }^{6}$ During the main period of the Middle Ages (ca. 700-1300), silver was almost the only key raw material in European coins. This depended on the existence of silver mines with a high supply of silver.

Normally, minted metal had premium value over un-minted metal in areas where the coins were legal tender, a disparity for which there are two basic economic explanations:

- First, minted metal works better as a medium of exchange and standard of value than does un-minted metal. When doing daily transactions it is manifestly more efficient and practical to count coins than to weigh silver and try to check the fineness. People are thus generally willing to pay a premium to have their silver transformed into standard coins (Sussman 1993:50).

\footnotetext{
${ }^{5}$ Fiat money has historically been "money by decree". Authorities through legal tender laws have forced people to accept the fiat money as a medium of exchange.

${ }^{6}$ Precious metals: 1) exist in limited quantities, are 2) well-known, 3) of stable value and 4) relatively soft and thereby easy to work up. The last characteristic explains why coins cannot contain 100 percent gold or silver. Instead, these precious metals are mixed with zinc or copper - as the coins otherwise would be worn down in routine use.
} 
- Second, coins are a typical "network good". The individual value of holding coins increases the more people accept the coins as a medium of exchange and a standard of value (Dowd and Greenaway 1993:1180ff). Hence the premium component is reinforced and tends to grow.

In practice it is the agents in the market who determine the level of this premium component that enable the coin issuing authority to make a profit (gross seignorage) from minting. ${ }^{7}$

In the Middle Ages the king/emperor possessed the rights to mint, charge market customs and run mines. The coinage right encompassed the right to (Kluge 2007:52): 1) decide which coins are legal tender, i.e. which coins are legitimate and valid as a medium of exchange, 2) determine the monetary standard, including denomination, weight, fineness, diameter and relief, 3) coin and determine design and 4) make a profit from minting.

The right to mint for a region and make a profit could be delegated, sold or pawned to other authorities (laymen, churchmen, citizens) for a limited or unlimited time period (Kluge 2007:53). ${ }^{8}$ In general, these authorities had to observe the king's guidelines for valid coins and the monetary standard, but there were exceptions. ${ }^{9}$ The most common reason to delegate the coinage right was that a bishop or layman founded a town and thereby financed the associated costs. But delegation could also be exchanged for loyalty to the king/emperor. The rights to mint and charge market customs were typically delegated together, since the coin issuer also had to control the market. The market custom was a fee for the craftsmen and merchants' goods brought to and sold in the town market. This stated purpose of the fee was to support the market, but it was also important recurring revenue for the authority.

The size of the currency areas bounding the right to mint could vary substantially in the Middle Ages. In England, Sweden and Denmark, the king normally retained the coinage right and had a pure monopoly. Exceptions were some mints controlled by bishops. The whole of England was a single currency area, while Sweden and Denmark each had 2-3 areas. The currency areas in these countries were thus relatively large, each having several mints. In

\footnotetext{
${ }^{7}$ Gross seignorage $=$ net seignorage + production costs. In the Middle Ages, the gross seignorage could vary substantially over time; for example, in Sweden from 5 to 50 percent between 1300 and 1500 (Edvinsson et al. 2010:102). Production costs were around 5 percent (Sussman 1993:55).

${ }^{8}$ Pawning of the coinage right means that the possessor of the minting right borrows money from an external person. As a pawn for the loan, the pledgee runs the mint for a specific period and receives the minting revenues as a payback of the loan.

${ }^{9}$ For many regions in Germany in the $12^{\text {th }}$ and $13^{\text {th }}$ centuries ecclesiastical mints decided the monetary standard.
} 
contrast, in France the minting right was delegated to many civil authorities and there were many small currency areas. Germany in the High Middle Ages was extremely decentralized politically with a weak emperor. One method the German emperor used to strengthen feudal loyalties was to delegate land; another was to delegate the rights to mint and charge market customs. The best examples of many small currency areas can be found in Germany and eastern Europe where a city (mint) along with its surroundings could constitute a currency area. Unlike in France, ecclesiastical authorities in Germany frequently received the coinage rights.

\subsection{Coinage systems in medieval Europe}

For purposes of analysis, the coinage systems in the High Middle Ages of Europe (ca. 10001300) are divided into two main types. One system had long-lived coins that were valid during the whole reign of the coin issuer. ${ }^{10}$ The other system had short-lived coins that were only valid for specific intervals in the issuer's reign. ${ }^{11}$ In the latter system, old coins were frequently declared invalid and exchanged for new ones at publically announced exchange rates and dates. The monetary standard (denomination, weight, fineness, diameter, shape of the flan) remained the same at re-coinage, only the image of the coins was changed. An exchange fee was charged as a way to tax trade and inhabitants; for example, the fee could be four old coins for three new ones, i.e. a gross seignorage of 25 percent. Documents and empirical observations show that re-coinage could occur annually or even twice a year within a currency area in the Middle Ages (Kluge 2007:62ff).

There is a consensus in the conclusions drawn about the extension through time and space of long-lived and short-lived coinage systems. As can be seen on Map 1, long-lived coins were common in western and southern Europe (France, Italy, Christian Spain and England after 1150) in the High Middle Ages, whereas, short-lived coins dominated in central, northern and eastern Europe (Germany, Austria, Scandinavia, Poland Bohemia/Moravia and England before 1150) (Kluge 2007:62ff). The short-lived coinage system defined legal tender for almost 200 years in large parts of medieval Europe.

\footnotetext{
${ }^{10}$ Sometimes, successors minted variants of the same coin type. These are called immobilized types and could be valid for very long periods - occasionally centuries - surviving the reigns of several successive rulers.

${ }^{11}$ The term "feudal pennies" refers to a system where the coins are limited through time and space. In this system the right to mint is delegated to civil and ecclesiastical authorities. The term "regional coins" is widely used instead for a short-lived coinage system. But the term "regional" is misleading inasmuch as long-lived coins also had a geographical constraint and were regional. For example, the two-faced French coins minted by civil authorities between 900 and 1200 were only valid in small regions. The large difference between different medieval coinage systems is their validity measured over time.
} 
Map 1. Short-lived and long-lived coinage systems in Europe 1140-1300.

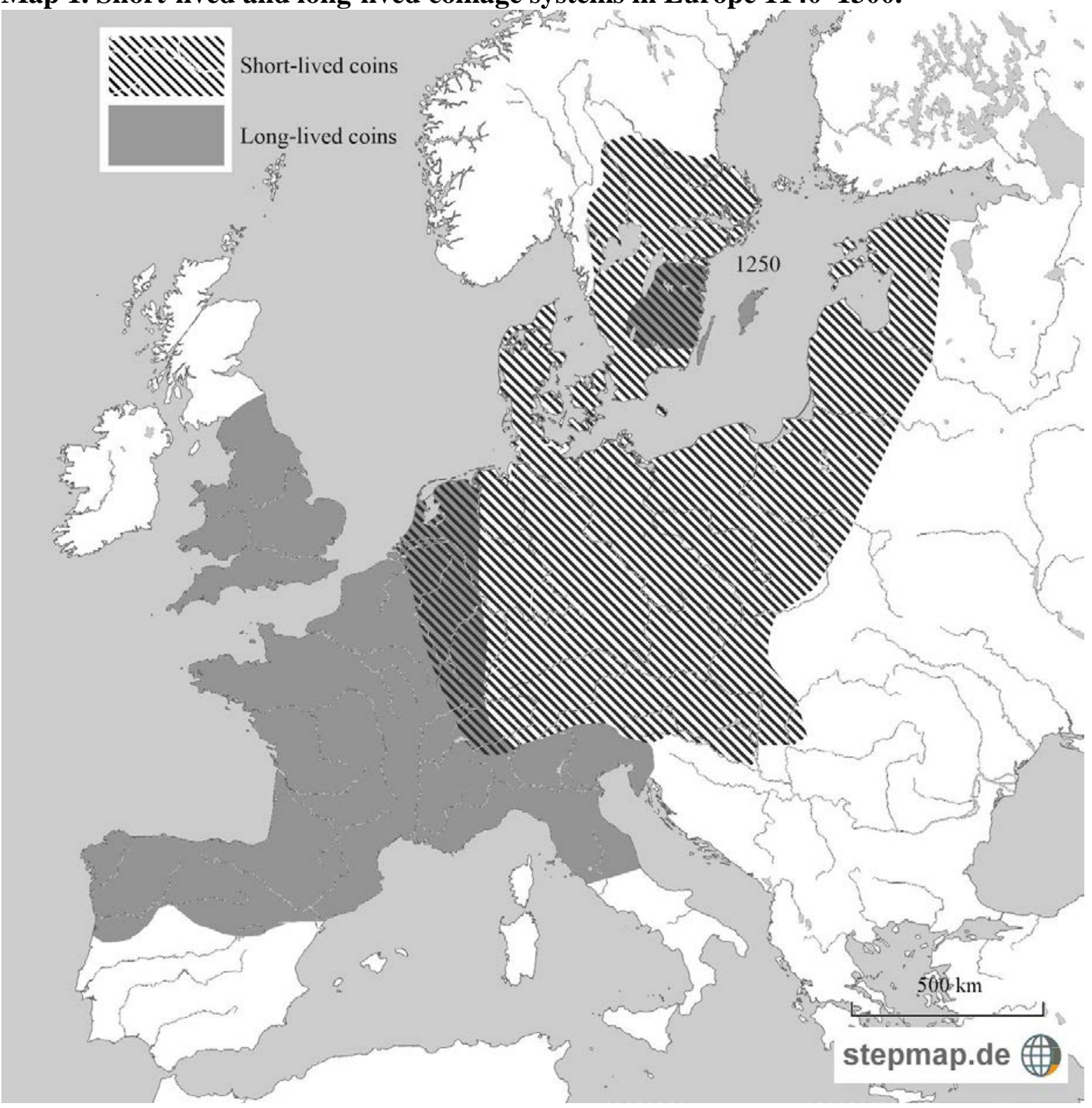

Note: Eastern Götaland, Sweden, changed from long-lived (Gotlandic) to short-lived (Swedish) coins in 1250.

In areas with long-lived coins, the same coin type was produced in all mints of the currency area. The purpose of long-lived coins was to create a high acceptance for the issuer's coins both inside and beyond his own currency area; for example, in international trade. With this expansion the issuer could strike more coins and make a higher profit. The most important source of income for the minting authority in such a system was probably the monopoly over the exchange of foreign coins and bullion for current local ones (Kluge 2007:62-63).

England had re-coinage ca. 975-1130/35, as did eastern parts of France and western parts of Germany in the $11^{\text {th }}$ and $12^{\text {th }}$ centuries (Spufford 1988:92-94, Hess 2004:19-20). However, 
the best examples of short-lived and geographically constrained coins can be found in central and eastern Germany where currency areas were relatively small. Here, re-coinage started in the middle of the $12^{\text {th }}$ century and lasted until the beginning of the $14^{\text {th }}$ century. Re-coinage could occur annually or twice a year (Kluge 2007:63). ${ }^{12}$ Like Germany, Poland had many currency areas and minting authorities. At the end of the $12^{\text {th }}$ century renewals were annual, and in the $13^{\text {th }}$ century they occurred twice a year. Bohemia also had re-coinage at least once a year in the $12^{\text {th }}$ and $13^{\text {th }}$ centuries (Paszkiewicz 2011). ${ }^{13}$

\subsection{Conditions for short-lived coinage systems}

The basic similarities and differences between the coinage systems are depicted in Table 1. Both short-lived and long-lived coinage systems require a geographical currency constraint (foreign coins are invalid) and an exchange monopoly. Furthermore, the coin issuing authority must control both the local market and the coinage. This is facilitated if the rights to charge market customs and to mint are possessed by a sole authority, which in medieval Europe normally was the case (Kluge 2007:63).

If a system with re-coinage is going to be practical, it is essential that: 1) only one type circulates, and 2) it is easy for users in everyday life to distinguish between various issues. It is then requisite that differences in the main design on the coins are carefully linked to different issues. In addition, details on the coins are used by the minting authority to control the coinage. $^{14}$

As was concluded in the previous section, re-coinage was the dominant monetary policy in the central, eastern and northern parts of Europe. These areas were relatively undeveloped and had less experience of coinage and local markets than western and southern Europe. Recoinage works particularly well in such relatively undeveloped economies, since there is a small volume of coins circulating. This key factor facilitates re-minting. Furthermore, there

\footnotetext{
${ }^{12}$ Individual German mints had annual renewals until the beginning of the $15^{\text {th }}$ century (e.g. Brunswick until 1412) (Kluge 2007:105).

${ }^{13}$ Austria had annual re-coinage until the end of the $14^{\text {th }}$ century, Brandenburg until 1369 (Kluge 2007:119) and the Teutonic Order in Eastern Prussia every tenth year between 1237 and 1364 (Paszkiewicz 2008:178). Sweden had coin renewals of bracteates in two of three currency areas (especially in Svealand and to some extent in western Götaland) for more than a century, from 1180-1290. This conclusion is supported by evidence of numerous coin types per period and the composition of coin hoards (Svensson 2012:208ff). The King of Denmark introduced frequent re-coinage (mostly annual) from the mid of the $12^{\text {th }}$ century that continued for 200 years with some interruptions (Grinder-Hansen 2000:61ff).

${ }^{14}$ The differences in details thus had numerous sources and may have diverse explanations, e.g., different mints, weights, fineness or mint masters. The name of the mint could also be included in the legend.
} 
also are few places where coins are used for transactions and few groups in society who use coins, i.e. low monetization. The latter facts facilitate monitoring and enforcement of a shortlived coinage system (Svensson 2013a:9-10).

Table 1. Similarities and differences between long-lived and short-lived coinage systems

\begin{tabular}{lccc}
\hline \hline Conditions/Characteristics & $\begin{array}{c}\text { Long-lived } \\
\text { coins }\end{array}$ & $\begin{array}{c}\text { Short-lived } \\
\text { coins }\end{array}$ \\
\hline \hline Geographical constraint (foreign coins invalid) & Yes & Yes \\
\hline Exchange monopoly & Yes & Yes \\
\hline Market right necessary & Minting of bullion (gross seignorage) & Yes & Yes \\
\cline { 2 - 4 } $\begin{array}{l}\text { Profit of the } \\
\text { coin issuer }\end{array}$ & Re-minting of foreign coins (gross seignorage) & Yes & Frequent \\
\cline { 2 - 4 } & Re-coinage and issues (exchange fee) & Only when shift \\
of issuer & Often & Sometimes \\
\hline Number of coin types (same denomination) circulating & One or few & One \\
simultaneous in a given currency area & Large & Small \\
\hline Volume of coins circulating in the economy & High & Low \\
\hline Relative development of the economy & Large or small & Preferably small \\
\hline Geographical area & Few & Many \\
\hline Number of mints in large currency areas & &
\end{tabular}

Re-coinage is more easy to accomplish if the currency area is small with only one mint (e.g. German currency areas) than if the currency area is large with many mints (e.g. England). In the latter case, some degree of state structure is needed. In Germany a short-lived coinage system with only local new coins as legal tender was typically enforced only within a city's borders, and any coins could be used outside the city (Hess 2004:16). The coin issuing authority had several methods to monitor and enforce the re-coinage. First, there were exchangers and other administrators at the city markets. Second, the re-coinage date was often designated just prior to an important annual market or the payment date of an annual tax. Third, payment of any fees, taxes, rents, tithes or fines had to be made in new coins (Svensson 2013:13ff).

\section{The economic function of bracteates}

\subsection{Extension of bracteates through time and room}

The minting of bracteates started around 1120 in Thuringia and Saxony-Meissen in Germany (see more in section 3.2.1). It was not until the 1140s that the bracteate technology spread to 
Harz, Anhalt, Magdeburg and Upper Lusatia. In the 1150s mints in southern Lower Saxony, Brandenburg and northern Hessen began to strike bracteates. In the 1160s the bracteates reached southern Hessen (Wetterau), and in the 1180s northern Lower Saxony (see Map 2).

Map 2. Spreading of the bracteate technology 1120-1270.

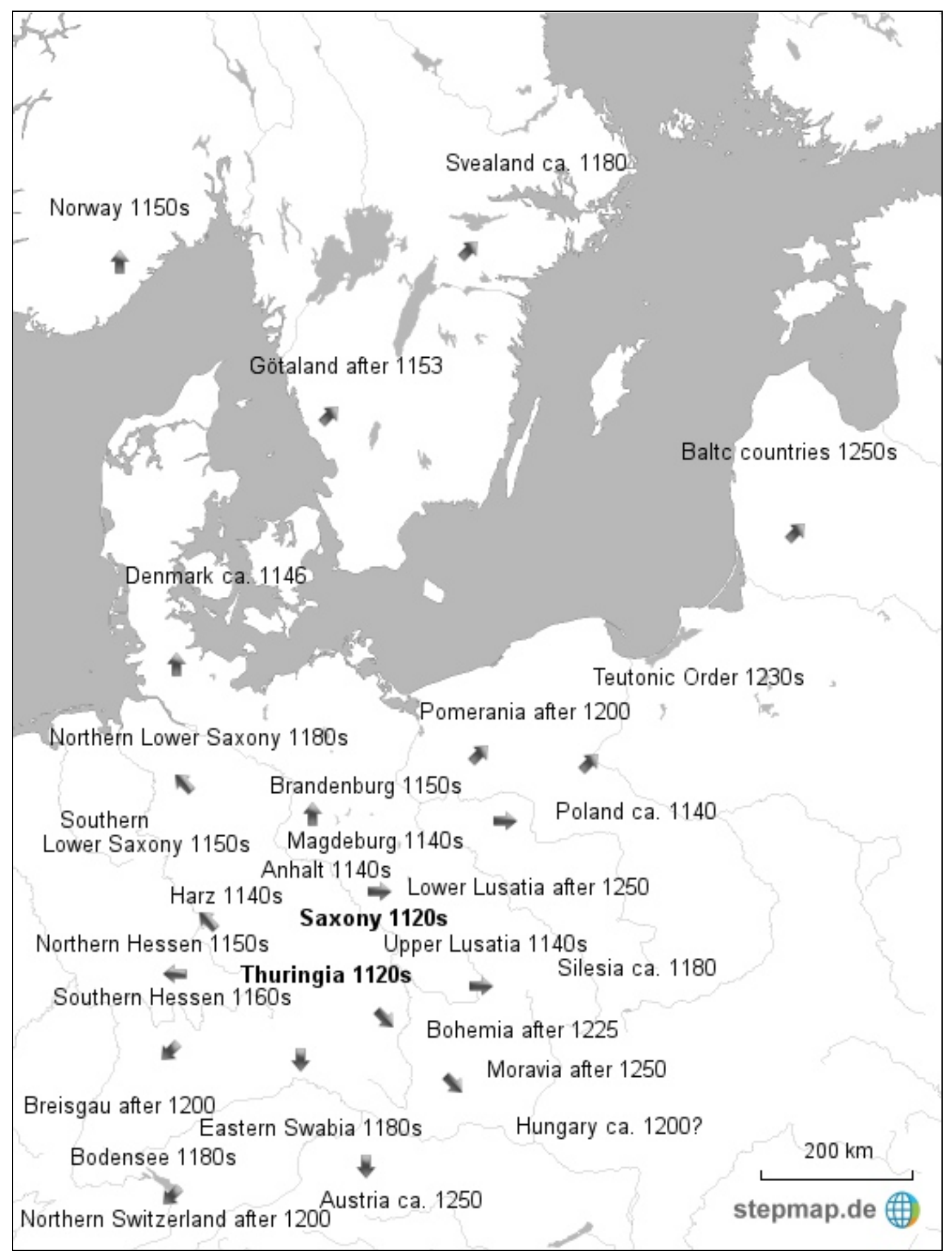


Norway and Sweden (Götaland) started to mint bracteates in the 1150s. Sporadic minting also occurred in northern Jutland in Denmark around 1150. Mints in the Bodensee region and eastern Swabia did not start striking bracteates until the last two decades of the $12^{\text {th }}$ century, and in northern Switzerland and Bresigau at the beginning of the $13^{\text {th }}$ century. Eastwards, by around 1140 the bracteate technology spread to Poland, and in the $13^{\text {th }}$ century to Lower Lusatia, Pomerania, Bohemia, Moravia, Austria and Hungary; and north-eastwards to eastern Prussia (Teutonic Order) and the Baltic area (Livonian Order) (Kluge 2007:99ff).

Comparing Maps 1 and 2, it can easily be concluded that bracteates in their main period 11401320 were minted exclusively in areas with short-lived coinage systems. However, two-faced coins were also minted in areas with frequent re-coinage, for example in western parts of Germany (Rhineland, Westphalia and Franconia), Austria and Denmark as well as in Bohemia and Moravia before 1225 (see section 4). An interesting observation from Map 2 is that bracteates were coined in relatively undeveloped areas with limited experience of minting.

Ecclesiastical and civil authorities were mainly responsible for the minting of bracteates especially in northern and central Germany. The emperor only directly controlled a few mints. However, many of the bracteate mints with extensive coining were in the possession of the emperor (e.g. Lübeck, Goslar, Frankfurt am Main, and Nordhausen). Thuringia is the region which minted the most diverse types of bracteates. The region from 1140-1270 had at least 50 mints (Steguweit 1987:16). Magdeburg and Brunswick (southern Lower Saxony) are the mints that issued the greatest variety of bracteate types - at least 300 to 400 each.

\subsection{Economic purpose of bracteates}

It is wise to bifurcate the difficult general question "Why were bracteates minted?" into more specific questions: 1) Why were the first bracteates minted at all?; and 2) How could bracteates get such a foothold as the chief form of coinage in large parts of Germany as well as northern and eastern Europe, over the course of more than 150 years?

\subsubsection{The first bracteates}

A reliable explanation as to why the first bracteates were minted at all has been presented by Kühn (1996:15ff). He argues that the first bracteates were a temporary solution to supply a medium of exchange in the growing local markets in Thuringia. In the early $12^{\text {th }}$ century 
Germany was experiencing accelerated population growth. To satisfy the increased demand for food, more land had to be cultivated, partly in the woods and partly through expansion eastwards in Europe. The intensity and productivity in agriculture also improved. This was due to the expansion of three-year crop rotation, better tools and use of more flexible means of assistance, e.g. horses instead of oxen (Gerlich 1986:124).

The surplus of manpower accelerated the division of labour. For new specialized occupational groups like handicraftsmen, it was necessary to get food in exchange for handicraft products at weekly or monthly local markets. These markets were often located close to administrative centres (bishop residences, monasteries or castles), which quickly matured into small towns. Many of the specialized groups (e.g. handicraftsmen and merchants) preferred to settle down in these growing towns - close to the physical market they depended on.

If the local markets were to work efficiently, coins were needed that had the functions of being both a medium of exchange and a standard of value. In the beginning of the $12^{\text {th }}$ century the only mint in Thuringia, Erfurt, was controlled by the Archbishops of Mainz. Erfurt was unable to satisfy the demand for coins in the whole of Thuringia (Kühn 1996:17). In the new local markets there must have been a large demand for coins as a medium of exchange. However, the new towns struggled to find any well apprenticed mint personnel.

This problem was likely solved by a couple of monasteries in Thuringia which stored relatively large deposits of silver and had goldsmiths available. These goldsmiths had never minted coins, but had a long tradition of working up precious metals. They engraved thin flans of precious metals and used a soft material as leather or lead under the flans (Kühn 1996:17ff). From 1115 to 1130 three Thuringia monasteries, in Pegau, Saalfeld and Nordhausen, started striking uni-faced coins that later would be called bracteates. ${ }^{15}$ It can be surmised from a technical analysis that these early bracteates must have been struck by individuals without any prior apprenticeship in coining (Kühn 1996:27). ${ }^{16}$ It has also been

\footnotetext{
${ }^{15}$ Bracteates were also coined early in Saxony-Meissen.

${ }^{16}$ For example, on a bracteate from the monastery Pegau, the legend is retrograde (see Picture 2). On another bracteate from the monastery in Saalfeld, the main design of the bracteate - a seated abbey or bishop with a book and a crosier - has a relief higher than the surrounding circle of pearls. This kind of elevation is very rare, since the perimeter should protect the main design from being worn down. Kühn (1996:27), suggests that this bracteate is produced with a stone matrix. A third bracteate from the monastery Nordhausen has been struck with a positive die from the reverse. All three of these bracteates were struck with a soft material under the flan and are technologically different from contemporary two-faced coins. The only reasonable conclusion to draw is that
} 
demonstrated that the bracteates were struck with a technology similar to that used by goldsmiths (Kühn 1996:20ff). A serious problem for the monasteries was that they did not have the right to coin from the emperor. However, by striking uni-faced pieces of silver unlike earlier known coins, the issuers were in a legal grey zone (Kühn 1996:25-26).

The local population certainly had no difficulty in accepting the bracteates as medium of exchange; they had almost no experience of coins. It was more difficult to persuade local and foreign merchants to accept the bracteates. It was then necessary to introduce a geographical currency constraint, where the local bracteates were exclusively the currently sanctioned coins. Thereby, from the beginning the bracteates got a local limited circulation area (Kühn 1996:19). What must be stressed is that there is absolutely nothing in the historical record to indicate the first bracteates were short-lived coins. To the contrary, they seem to have circulated during relatively long time periods. However, the inherent fragility of the bracteates was thereby an endemic problem, forcing the issuer to substitute new for damaged bracteates from the same issue (Röblitz 1985:16, Kühn 1996:19). One of the earliest bracteates is shown on Picture 2.

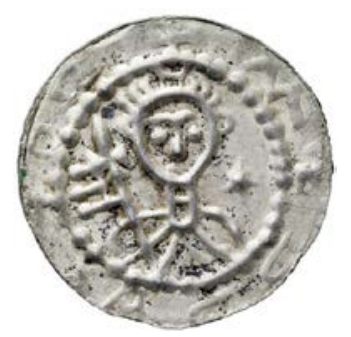

Picture 2. Bracteate, Pegau (Thuringia), Sheriff Wiprecht von Groitzsch (1091-1124), struck 1115/20. Bust of the sheriff with banner on lance, star in field, $0.72 \mathrm{~g}, \varnothing 21 \mathrm{~mm}$.

Legend: ADDZWITOUO (retrograde).

\subsubsection{Bracteates as short-lived coins}

Many researchers and collectors have wondered why such thin coins as bracteates were minted over such a long time period - from 1120 to 1550, serving as the main coin ca. 11401320. We may begin to see that a great many pieces of the puzzle fall into place once this kind of uni-faced coin is linked to re-coinage. The system of frequent re-coinage required a

these three early bracteates were each produced in a different way by individuals with little experience of coinage. 
continuous re-minting of coins. Even if the idea behind the first bracteates had nothing to do with re-coinage, bracteates turned out to be well suited to function as short-lived coins:

- Only one die was needed, which reduced production costs and time.

- Bracteate dies lasted longer than those for two-faced coins for two reasons. The soft material (leather or lead) under the thin flan implied that the hammer hit was cushioned, and the thin flan required less power when striking coins. A far larger number of coins could be minted with a specific die.

- The relatively large diameter (up to $50 \mathrm{~mm}$ ) made it possible to display various images on the coins. This made recognition of valid and invalid coins fast and reliable (see examples on Pictures 3-5).

- The bracteates were fragile, but were not in circulation for a long period due to routine frequent renewals.

- $\quad$ Old bracteates were easy to hammer out and overstrike (Dobras 2005:9).

There may well also have been political motives for striking bracteates. Artistically designed coins were excellent marketing instruments for the coin issuer. The thin flan also proved practical, making it easy to cut the bracteates into halves (Hälblinge) or quarters (Vierlinge) when the need arose. Sometimes this was done at the mint (Dobras 2005:9). Halved bracteates are quite common in German coin hoards (Svensson 2013b:139, Table 13).
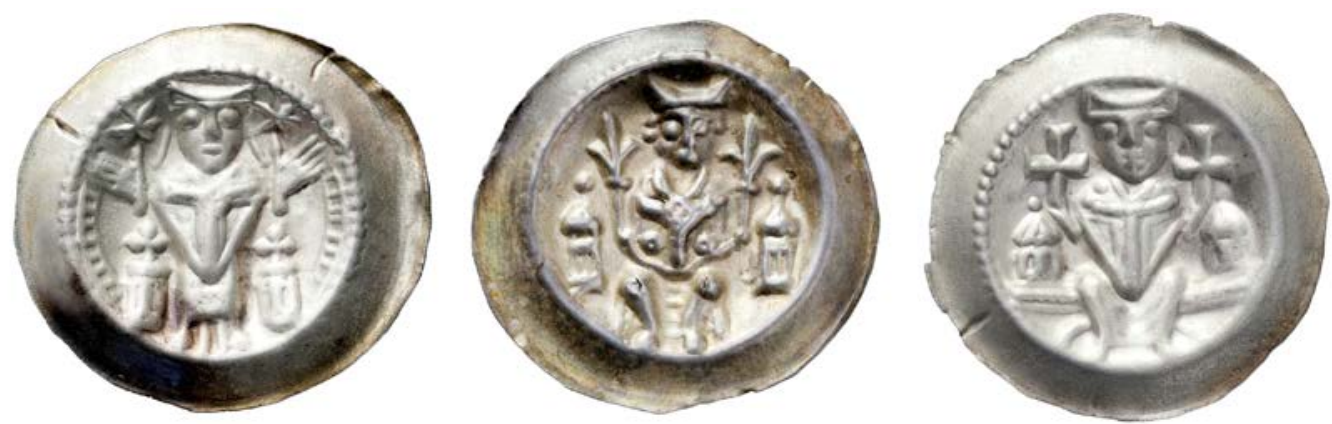

Pictures 3-5. Only the image changes at re-coinage. Three bracteates from the mint Hildesheim (Lower Saxony), Bishop Konrad II or successors (1240-60).

Weights and diameters: $0.69 \mathrm{~g}, \varnothing 26 \mathrm{~mm} ; 0.70 \mathrm{~g}, \varnothing 26 \mathrm{~mm}$ and $0.79 \mathrm{~g}, \varnothing 27 \mathrm{~mm}$.

Another economic motive might have been the minting authority hoped the fragile coins would be damaged when circulating. In that circumstance they could then be exchanged at a discount, giving the issuer an extra profit. In the $12^{\text {th }}$ century many bracteates were notoriously so fragile they could not be kept in ordinary purses, which was the normal practice with coins in the Middle Ages. Instead, the bracteates were kept in special boxes or 
tins made from wood, leather or metal (Wagner 1998:9). The two most common alternative medieval containers for bracteates were bracteate boxes (Brakteatendosen) or bracteate bowls (Brakteatenschale).

It is possible that after around 1250 multiple bracteates were simultaneously struck by placing several flans above each other, which would increase the efficiency of coining. This is a particularly valuable technique when renewals are frequent. However, nobody has yet been able to persuasively demonstrate that this method of coining occurred (Kühn 2000:13).

During the Middle Ages people routinely scraped off silver from the edges of their coins which over time could yield a tidy sum. In England in 1247 the creative response was a coinage reform where short cross pennies were replaced by new ones with a long cross that extended to the outer edge. This simple design change made the practice of scraping visible and hence more difficult to pass. On the other hand, bracteates were very fragile and it was almost impossible to scrape off silver from the edge without damaging the whole coin. By virtue of coining bracteates, mints severely hindered silver thieves.

Another factor encouraging the minting of bracteates was that they were far more difficult to counterfeit than two-faced coins. One written document tells us that it was for this reason that Brandenburg planned to reintroduce bracteates (hohlpennies) instead of striking two-faced coins in the 1340s (Mäkeler 2010:36).

In Germany and other parts of Europe in the $12^{\text {th }}$ and $13^{\text {th }}$ centuries re-coinage was commonplace for both bracteates and two-faced coins. Thus, while minting of bracteates is clearly not a necessary condition in itself for re-coinage, it is in effect a sufficient condition. Whenever one finds a bracteate struck in Germany, central or eastern Europe in the period 1140-1300, it is almost 100 percent certain that it was linked to frequent coin renewals.

\section{Bracteates vis-à-vis two-faced coins}

When the Carolingian empire broke down politically in the $10^{\text {th }}$ century, Germany had a relatively uniform coinage with respect to weight and fineness while the German emperor controlled the minting. As Germany in the $11^{\text {th }}$ and early $12^{\text {th }}$ centuries became more 
decentralized politically, this was reflected in the growing heterogeneity with respect to control of coinage rights (bishops and laymen). The German coins became more diverse

As the decentralization of the German coinage continued, more mints issued coins that had temporal and spatial constraints. Examples of mints that soon applied re-coinage in the eastern French and western German region were Dinant from 1047 to 1064, Verdun 1069-99 and 1131-56, Toul from the end of the $10^{\text {th }}$ century, Saint-Mihiel in 1099, Strasbourg after 1129 and Marmoutier (Maursmünster) in 1144. For the mint Speyer, 25 different types can be dated during 80 years between 1046 and 1125 (Hess 2004:19-20). In Liège (Lüttich) many types of coins were minted at the close of the $11^{\text {th }}$ and early $12^{\text {th }}$ centuries. This is in line with those complaints against renewals forwarded to Bishop Othbert (1092-1119) in Liège.

The German coin hoards from the periods of the Ottonian (962-1024) and Salian (10271125) imperial dynasties support the notion that by the $11^{\text {th }}$ century coins already had a constrained validity through time and space. The hoards are dominated by coins from a single mint. In addition, some hoards contain only one type of coin (Hess 2004:12, 20).

German coinage was split into two approaches in the last years of the $11^{\text {th }}$ and beginning of the $12^{\text {th }}$ centuries. Both groups of coinage issuers used re-coinage and decreased the weight of the coins. Some traditional mints in Rhineland, Westphalia and Franconia made their coins smaller in diameter, e.g., Cologne, Aachen, Mainz, Nuremberg and Regensburg (see Map 3).
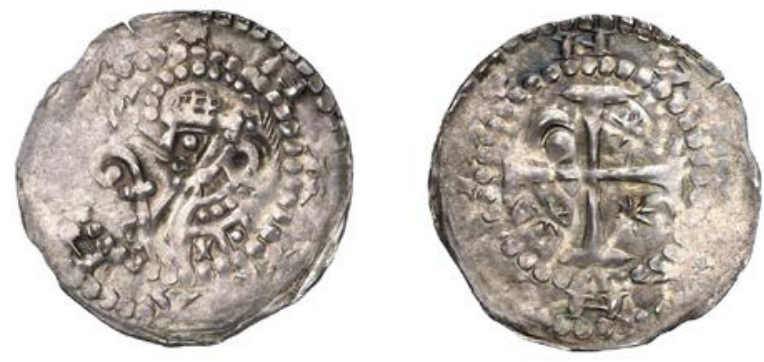

Picture 6. Worms (Southern Hessen), Bishop Burchard II von Asorn (1120-49), half-bracteate. Bust of the Bishop turned to the left with crosier, ears of corn behind him)(Large cross with three stars and one pellet with crescent in the angles, legends: +HANAH..)(..HA..H, $0.79 \mathrm{~g}, \varnothing 23 \mathrm{~mm}$.

Other mints - particularly the new ones in central and eastern Germany - increased the diameter of the flan, which thereby became thinner. Consequently, the obverse and reverse 
designs were superimposed upon each other. These exceedingly thin two-faced coins are called half-bracteates or Dünnpfennige (see Picture 6).

The conventional view has been that the bracteates were direct successors of the halfbracteates minted in Germany from 1050 to 1200. From this point of view it is simply necessary to imagine that some mint master one day had just decided to only use one die, thinking thereby the design would be better and the minting would become more efficient. But this now appears to be simply unfounded speculation. It was in all probability rather goldsmiths in monasteries in Thuringia, artisans who had never struck coins, that actually struck the first bracteates. There is persuasive technical evidence to support this alternative reading of the initiation of an innovation which was adapted by a significant part of Europe for centuries (see section 3.2.1). The purpose was to supply the growing local markets with a medium of exchange and a standard of value (Kühn 1996:15ff).

Bracteates were coined by mints that never had coined before. Among established mints in central Germany in the $12^{\text {th }}$ century, it was those that previously had minted half-bracteates which continued to mint bracteates. This was certainly a consequence of the poor artistic design of the half-bracteates, along with the fact that they were so weakly struck. Presumably, it was easier for people to accept the fragile bracteates in areas where coins had not circulated before, or where weakly struck half-bracteates had circulated rather than stable two-faced coins. In the $12^{\text {th }}$ century there were several mints that struck half-bracteates and bracteates simultaneously (e.g. Halberstadt and Quedlinburg). Other mints (e.g. Worms) increased the diameter of the flan and struck half-bracteates.

A rule of thumb is that bracteates got a foothold in regions with comparatively little experience of monetary economics, and where no monetary standard was established. A good example is Mainz, whose Archbishops controlled several mints (Kluge 1979:134-35). Mainz is located in the Rhineland where the penny of Cologne was dominant, having since the $11^{\text {th }}$ century determined the monetary standard for the whole region. The archbishops' own residence Mainz had long experience of monetary economics, and hence two-faced coins were routinely minted. But in their mints in relatively undeveloped regions like Thuringia (Erfurt and Heiligenstadt) and Hessen (Fritzlar, Amöneburg and Aschaffenburg) bracteates were coined (Dobras 2005:9). 
Map 3. German mints from 1140-1270 that mainly struck bracteates and two-faced coins.

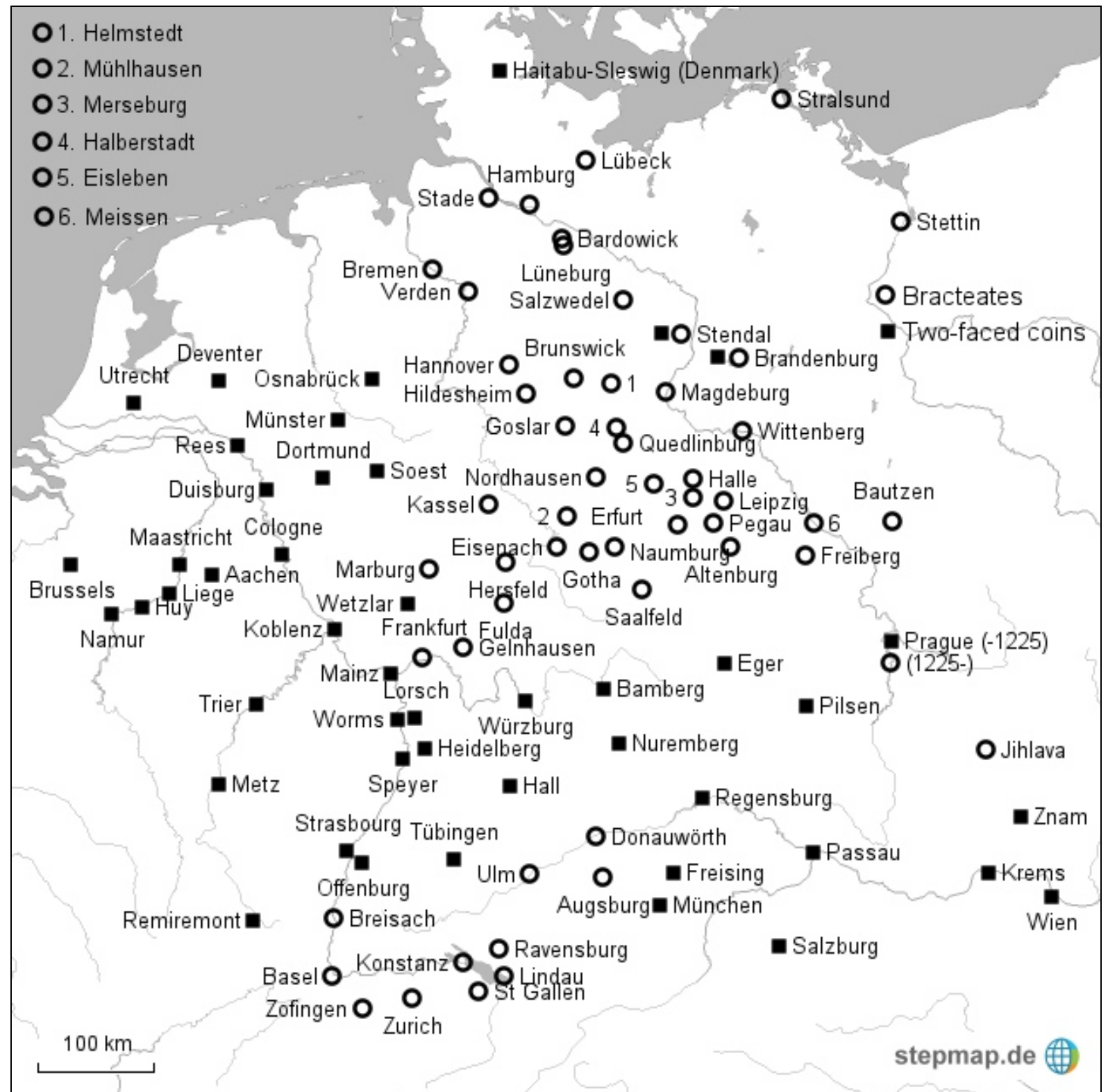

Note: The map only shows important mints. In Brandenburg and Stendal only bracteates were minted from 1150-1200 and 1180-1200, respectively. Bracteates and two-faced coins were simultaneously minted from 1200-50, and afterwards only two-faced coins.

Germany thus simultaneously had two-faced coins and bracteates, both of which were shortlived coins (see Map 3). In general, there was a geographical currency constraint in both cities, those with two-faced coins and those with bracteates. The bracteates dominated in northern and central Germany, east of the river Weser and north of the river Main, i.e. along the coast of the North Sea and the Baltic Sea, and in Lower Saxony, Harz, Anhalt, Brandenburg, Saxony-Meissen, Thuringia and Hessen. Areas in Baden-Württemberg (Bodensee region), Bavaria (eastern Swabia) and northern Switzerland also struck bracteates. In the rest of Germany - above all in Rhineland, Westphalia and Franconia - the traditional 
two-faced penny dominated. These were sometimes struck as half-bracteates, but the issuers did not continue and go on to bracteates.

Table 2. Characteristics of short-lived two-face coins and bracteates.

\begin{tabular}{lcc}
\hline \multirow{2}{*}{ Characteristics } & \multicolumn{2}{c}{ Short-lived coins } \\
\cline { 2 - 3 } Frequency of coin renewals & Two-faced coins & Bracteates \\
\hline Imitations & Several years to annually & Mostly annually \\
\hline Economic development of region & Sometimes & Rare \\
\hline Experience of own minting & Moderate & Low \\
\hline Number of coins in circulation & Moderate/Long & Low \\
\hline
\end{tabular}

Table 2 shows the basic differences between mints that struck short-lived coins in the form of two-faced coins and bracteates. Generally, coin renewals were more frequent in areas with bracteates than in regions with two-faced coins (Kluge 2007:63). Bracteates were often annually re-minted - sometimes biannually. The higher frequency of re-coinage in regions with bracteates is logical, since these regions in central and eastern Germany were less economically developed and had fewer coins in circulation. The fact is that when the bracteates started to be struck in the eastern regions in the 1140s, the more developed western regions of Germany (e.g. Rhineland-Westphalia) had already passed the zenith of renewals (Hess 2004:21).

In Westphalia and Rhineland where two-faced coins were struck, the frequency of the renewals varied. According to written documents dated to 1196 and 1226, the mint Speyer had annual renewals (Hävernick 1931:133). In dramatic contrast, each successive archbishop in Trier issued only one penny type and one half penny per reign between 1155 and 1299 (Hess 2004:18). ${ }^{17}$ At the beginning of the $14^{\text {th }}$ century, the archbishop in Trier had the right to renew the coinage three times per reign (Hävernick 1931:133-34).

Another written document says that the Archbishop and the city of Cologne in 1252 agreed re-coinage should be commemorative. They would occur only when a new bishop was appointed or when the archbishop travelled to Rome to participate at an imperial coronation. Similar rules were valid for the imperial mint Dortmund and enshrined in the city laws from

\footnotetext{
${ }^{17}$ An exception is Archbishop Dietrich II (1212-42), who issued two types of pennies.
} 
the mid $13^{\text {th }}$ century (Hävernick 1931:133). ${ }^{18}$ However, these are relatively late sources. Prior to 1252, if one looks at the number of types per time period (Hävernick 1935), there must have been more frequent renewals in Cologne. In general, there should have been on average 5-6 years between the renewals in the period 1130-1250. Archbishop Philipp von Heinsberg (1167-91) had five types over 24 years when there was only one imperial coronation in Rome (in 1190).

One document from 1166 suggests the emperor would have abolished coin renewals in Aachen after complaints against them. However, other written sources from 1255 and 1282 state that the coins were valid for ten years in Oppenheim and Aachen (Hävernick 1931:13334).

\section{End of the bracteates as the main coin type}

\subsection{Increased monetization and international currencies}

The system with short-lived coins and recurrent issues continued in Germany until the end of the $13^{\text {th }}$ and beginning of the $14^{\text {th }}$ century. The pressure from increased trade and commitment to multi-regional coin types - Heller and Groschen - crowded out the short-lived coins. It was not uncommon for citizens paid a fee to escape re-coinage. ${ }^{19}$ It also happened that re-coinage continued and was a legitimate practice in specific regions. For example, the Teutonic Order did this every tenth year until 1364 (Paszkiewicz 2008:178), and Brunswick until 1412 when "ever-lasting" pennies were introduced (Kluge 2007:105). Brandenburg had re-coinage of two-faced coins annually until 1369. The two-faced "Wiener-pennies" in Austria were brought in for re-coinage every year until the end of the $14^{\text {th }}$ century.

The decline of the bracteates as the main coin type and short-lived coins in general depended on developing economies, growing cities and increased local and inter-regional trade. Another factor reinforcing their demise was that a growing number of peasants paid rents and taxes to their landlords and kings in coins, rather than in kind or in services. This general evolution from a gemeinschaft to a gesellschaft culture required more coins in circulation, gradually making short-lived coins with geographical constraints impractical (Haupt 1974:59-60).

\footnotetext{
${ }^{18}$ In this case, there was also a re-coinage if the pledgee of the mint joined the journey to Rome.

${ }^{19}$ This was the case in France, Denmark and many cities in Germany, e.g. Augsburg and Konstanz (Svensson 2012:57-58).
} 
There was neither time to re-mint all the circulating coins nor the capacity to monitor the increased volume of coins in circulation. Finally, another trend typifies the burgeoning prosperity of a society undergoing urbanization. The use of coins with higher denominations and without regional constraints, e.g. Schilling, Heller, Groschen, Goldgulden, Ducats, rapidly expanded. These coins often crowded out local coins and were used more and more in international trade. These factors of course all blended together and made it near impossible for abbeys and laymen to hold on to their local coin monopolies.
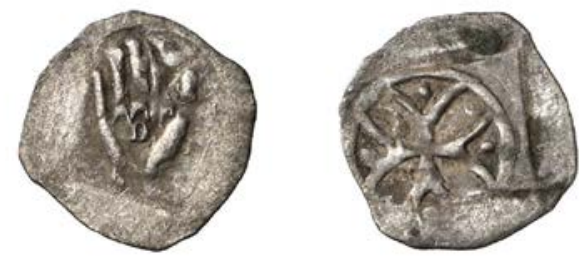

Picture 7. Handheller, Eastern Swabia, probably Augsburg (14 ${ }^{\text {th }}$ century).

Hand with small D )(Cross with small pellet in each cross end, $0.47 \mathrm{~g}$, Ø $16 \mathrm{~mm}$.

The Heller was the two-faced coin type that caused a decline of bracteates and other shortlived coins in southern and central Germany (see Picture 7). The Heller was first struck in the imperial mint Hall in Swabia (close to Würzburg and Nuremberg on Map 4). The most notable attributes of the Heller were the enormous volume issued and far lower fineness (50 percent) than the bracteates. In the period 1225-50 it had trespassed upon other currency areas - in part where two-faced coins from Worms, Speyer, Mainz, Tübingen and Würzburg and in part where bracteates from the Bodensee region, eastern Swabia and southern Hessen were the current coins. Gradually, Nuremberg took over the mass striking of the Heller. It became a kind of national coin type without any geographical constraints (Nau 1977:97). ${ }^{20}$

Bracteates were minted as the main coin type until the end of the $13^{\text {th }}$ and beginning of the $14^{\text {th }}$ century in large parts of central, northern, eastern and southern Germany, as well as in neighbouring areas. Thereafter, bracteates continued to be struck for ca. 250 years until the beginning of the $16^{\text {th }}$ century, but then as hohlpennies which were small change to another main coin type (e.g. Groschen, Witten, Örtug). However, there were exceptions where

\footnotetext{
${ }^{20}$ It is worthwhile to mention here several points from a written document by emperor Friedrich II (1215-50) that privileged the imperial mint Nuremberg in 1219. First, merchants from Nuremberg were henceforth allowed to pay with Nuremberg coins in the imperial cities Donauwörth and Nördlingen. Second, the merchants were also allowed to exchange silver and gold in these cities. Third, the mint master in Nuremberg also had the right to mint in these cities (Gaettens 1963:71). Therefore, it is likely that the Heller was also coined in Donauwörth and Nördlingen. Donauwörth also minted bracteates between ca. 1190 and 1270.
} 
bracteates continued to be the main coin type in the $14^{\text {th }}$ and $15^{\text {th }}$ centuries, e.g. for the Teutonic Order in Prussia until 1364, in Brunswick (Lower Saxony) until 1412 and in Halberstadt (Harz) until 1350. In northern Germany (Hamburg, Lübeck), bracteates were also the main coin type until around 1360, but here the frequent renewals had long since come to an end.

\subsection{Hohlpennies as small change}

Even if re-coinage was abolished around 1300, bracteates continued to be struck until the middle of the $16^{\text {th }}$ century. From 1300 and onwards, the contraction in diameter of the bracteates in northern and central Germany led to the minting of so called hohlpennies, which were still bracteates. Hohlpennies are only 12-18 mm in diameter and struck with a very high relief (see Picture 8). Normally they weigh between 0.30 and $0.40 \mathrm{~g}$. The minting of hohlpennies started off during the $14^{\text {th }}$ century. Extensive minting of hohlpennies occurred above all in northern and central Germany and in Scandinavia. The hohlpennies were often introduced along with a larger two-faced coin type (Groschen, Witten, Schilling or Örtug) which was a replacement for the bracteate as the main denomination. The system of recoinage and short-lived coins was then abolished in favour of long-lived coins. The hohlpennies worked as small change and were only changed when the coinage was reformed. They could thus circulate for many years, as indicated by the many worn specimens found in coin hoards. The high relief that had evolved came in handy to stabilize the hohlpennies which passed through many hands and purses. The hohlpennies continued to be struck until the end of the $15^{\text {th }}$ century and early $16^{\text {th }}$ century.

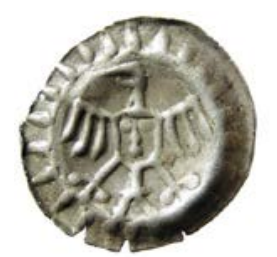

Picture 8. Salzwedel (Brandenburg), Margrave Joachim I (1499-1535). Eagle with head turned to the left, three feathers on each wing, shield on the breast, ray edge, $0.35 \mathrm{~g}, \varnothing 16 \mathrm{~mm}$.

There are obvious patterns in the development of bracteates evident over a longer period of time (1140-1550): The diameter became smaller, the relief higher, and the weight declined. The weight could continuously be diminished depending on the coin issuer's wish to make a higher profit. But it can also depend on the fact that people would put aside bracteates with higher weight at each issue. The silver content remained at a high level (90 percent) as long as 
frequent renewals occurred, at least until the late $13^{\text {th }}$ century (Svensson 2013a:19ff). Only when the re-coinage stopped and long-lived hohlpennies were introduced in the $14^{\text {th }}$ century did silver debasement increase.

\section{Conclusions}

Bracteates are thin uni-faced coins struck with only one die. A piece of soft material (leather or lead) was placed under the flan, thereby giving the characteristic mirrored image of the design on the reverse. Although the leaf-thin bracteates are the most fragile coins in monetary history, they were the main coin type for almost two centuries (1140-1320) in large parts of medieval Europe - especially in Germany, Switzerland, Poland, Bohemia, Moravia, the Baltic countries, Sweden and Norway.

The usefulness of the bracteates can be linked to the contemporary monetary taxation policy. Medieval coins were frequently declared invalid by the minting authorities and re-minted at specific dates. People then had to update their coins and pay an exchange fee (e.g. four old coins for three new ones). For such a policy, bracteates had several favourable characteristics: 1) Low production costs - only one die was needed and the bracteate dies lasted longer than those for two-faced coins; 2) Various pictures could be displayed given the relatively large diameter, making it easy to distinguish between valid and invalid types. Consequently, the fragility was not a big problem inasmuch as the issues of the bracteates were short-lived.

In Germany from 1140 to 1300 two-faced coins and bracteates were minted simultaneously. The former were struck in the western parts of Germany, Westphalia, the Rhineland and Franconia; the latter in the rest of the territory. An important observation is that the bracteates got a foothold in regions with comparatively less experience of monetary economics and where no monetary standard existed. Both two-faced coins and bracteates were linked to recoinage in Germany. Regions where bracteates were struck had more frequent renewals sometimes as often as twice a year. This is logical, since frequent renewals require a low monetization and the bracteates were easy to re-mint. The renewals in the western parts of Germany had already passed the zenith when the use of bracteates emerged and spread in the 1140s. The dominant mint in Rhineland, Cologne, renewed its coinage every fourth or fifth year. 
In general, the end of the bracteates as the main coin type and short-lived coins depended on increased monetization, developing economies and increased trade. This required a greater volume of coins in circulation, making re-coinage impossible to implement and monitor. At the same time, coins began to be struck with higher denominations and without regional constraints. Their gradual appearance and adaptation to emerging patterns of distribution and trade crowded out the bracteates. Examples of such coins were the Heller, Groschen, Witten and Goldgulden. During the Late Middle Ages, bracteates were struck in the form of hohlpennies, which were 12-20 mm in diameter, but had a higher relief. From the beginning of the $14^{\text {th }}$ to the beginning of the $16^{\text {th }}$ century the hohlpenny was small change to larger denominations (Groschen, Witten, Örtug, Schilling, etc.).

\section{References}

Dobras, Wolfgang, 2005, Münzen der Mainzer Erzbischöfe aus der Zeit der Staufer, Katalog der Brakteaten im Münzkabinett des Stadtarchivs Mainz. Beiträge zur Geschichte der Stadt Mainz, Vol. 34. Stadt Mainz, Mainz.

Dowd, Kevin and Greenaway, David, 1993, "Currency Competition, Network Externalities and Switching Costs: Towards an Alternative View of Optimum Currency Areas". The Economic Journal, 103(420), pp. 1180-89.

Edvinsson, Rodney, Franzén, Bo and Söderberg, Johan, 2010, "Swedish Payment Systems 995-1534”, in Rodney Edvinsson, Tor Jacobson and Daniel Waldenström (eds.), Exchange Rates, Prices and Wages, 1277-2008. Ekerlids Förlag, Stockholm, pp. 67-132.

Edvinsson, Rodney, 2011, "Inflation before Paper Money: Debasement Cycles in SwedenFinland 1350-1594”. Scandinavian Economic History Review, 59(2), pp. 166-83.

Gaettens, Richard, 1963, Die Wirtschaftsgebiete und der Wirtschaftsgebietpfennig der Hohenstaufenzeit. Verlag A Riechmann \& Co, Lübeck.

Gerlich, Alois, 1986, Geschichtliches Landeskunde des Mittelalters: Genese und Probleme. Wissenschaftliche Buchgesellschaft, Darmstadt.

Grinder-Hansen, Keld, 2000, Kongamagtens krise. Det danske møntvæesen 1241-1340. Museum Tusculanums Forlag, Copenhagen.

Haupt, Walther, 1974, Sächsische Münzkunde, Deutsche Verlag der Wisssenschaften, Berlin.

Hess, Wolfgang, 2004, "Münzverrufungen der späten Pfennigzeit: Besonders in den Brakteatengebieten Mittel- und Südwestdeutschland”, in Lutz Ilisch, Sönke Lorenz and Heiko Steuer (eds.), Dirham und Pfennige 2. Mittelalterliche Münzprägung in Südwestdeutschland. Zeitschrift für Archäologie des Mittelalters. Beiheft 19. Dr Rudolf Habelt GmbH, Bonn, pp. $11-22$. 
Hävernick, Walter, 1931, "Münzverrufungen in Westdeutschland im 12. und 13. Jahrhundert”. Vierteljahrschrift für Sozial- und Wirtschaftsgeschichte, Vol. 24, pp. 129-41.

Hävernick, Walter, 1935, Die Münzen von Köln. Die königlichen und erzbischöflichen Prägungen der Münzstätte Köln, sowie die Prägungen der Münzstätten des Erzstifts Köln vom Beginn der Prägung bis 1304. Cologne.

Kluge, Bernd, 1979, "Probleme der Brakteatenforschung”. Forschungen und Berichte. Vol. 19. Staatliche Museen zu Berlin, Berlin, pp. 127-38.

Kluge, Bernd, 2007, Numismatik des Mittelalters: Handbuch und Thesaurus Nummorum Medii Aevi. Münzkabinett Staatlichen Museen zu Berlin and Verlag der Österreichischen Akademie der Wissenschaften, Berlin and Vienna.

Kühn, Walter, 1996, “Die Anfänge der Brakteatenprägung in Thüringen und ihre Entwicklung bis etwa 1150”. Gesellschaft für Thüringer Münz- und Medaillenkunde e.V. Jahrbuch 1995/96, No. 7, pp. 15-54.

Kühn, Walter, 2000, “Zur mittelalterliche Prägungstechnik”. Freiberger Münzblätter, No. 9. Freiberger Münzfreunde e.V., Arbeitskreis Sächsiche Münzkunde und Säschsiche Numismatische Gesellschaft e.V., pp. 1-16.

Mäkeler, Hendrik, 2010, Reichsmünzwesen im späten Mittelalter, Teil 1: Das 14. Jahrhundert. Vierteljahrschrift für Sozial- und Wirtschaftsgeschichte, Vol. 209. Franz Steiner Verlag, Stuttgart.

Nau, Elisabeth, 1977, "Münzen und Geld in der Stauferzeit”, in Christian Väterlein, Ursula Schneider and Hans Klaiber (eds.), Die Zeit der Staufer. Band III. Württembergisches Landesmuseum, Stuttgart, pp. 87-102.

Paszkiewicz, Borys, 2008, “A Chronology of the Teutonic Prussian Bracteates”, in Michael Andersen, Helle W. Horsnæs and Jens Christian Moesgaard (eds.), Magister Monetae. Studies in Honour of Jørgen Steen Jensen. National Museum, Copenhagen, pp. 171-186.

Paszkiewicz, Borys, 2011. Non-published correspondence in 2011. Instytut Archeologii, Uniwersytetu Wroclawskiego.

Röblitz, Günther, 1985, “Zum Umbruch des Geld- und Münzwesens in Thüringen während des 12. Jahrhunderts”. Jahrbuch Arbeitskreis Münz- und Geldgeschichte in Thüringen 1985, pp. 5-18.

Steguweit, Wolfgang, 1987, Geschichte der Münzstätte Gotha vom 12. bis zum 19. Jahrhundert. Hermann Böhlaus Nachfolger, Weimar.

Sussman, Nathan, 1993, "Debasements, Royal Revenues, and Inflation in France During the Hundred Years’ War, 1415-22”. The Journal of Economic History, 53(1), pp. 44-70.

Svensson, Roger, 2013a, "Re-Coinage as a Monetary Tax: Conditions, Consequences and Comaprisons with Debasement”. IFN Working paper No. 950, The Research Institute of Industrial Economics, Stockholm. 
Svensson, Roger, 2013b, Renovatio Monetae: Bracteates and Coinage Policies in Medieval Europe. Spink \& Son, London.

Wagner, Siegfried, 1998, Naumburger Münzen. Stadtmuseum Naumburg, Naumburg. 